\title{
Russian Indology: Periodization, Science and Education Organization, Problematics and Specialization
}

\author{
Guzel F. Mrathuzina ${ }^{1}$ \\ ${ }^{1}$ Kazan (Volga region) Federal University, Kazan, Russia \\ Correspondence: Guzel F. Mrathuzina, Kazan (Volga Region) Federal University, Kremlyovskaya street, 18, \\ Kazan 420008, Russia. E-mail: mgbox1005@gmail.com
}

\author{
Received: April 14, 2015 Accepted: April 20, 2015 Online Published: April 27, 2015 \\ doi:10.5539/jsd.v8n4p15 URL: http://dx.doi.org/10.5539/jsd.v8n4p15
}

\begin{abstract}
Thematic justification is conditioned by the study of the origins and patterns of Indology development, learning of accumulated historiographical material, the development of theoretical foundations of Indology, which will fix the domestic level of understanding of Indology development problems in Russia in XVIII-XX centuries. It is important to update Indology by new concepts, to promote knowledge of the history and culture of India people. These scientific and socio-ideological preferences are identified in studies of domestic indologists. This article aims to achieve the following objectives - theoretical and conceptual, historical and scientific understanding of the succession and identity of Russian Indology through its periodization and specialization description. Key approach to the study of this theme is the analysis and evaluation of the history of pre-revolutionary, Soviet and modern Indology, which raises the problem of preservation and revival of this fundamental science, understanding of trends in the evolution of classical and practical Indology in Russia. The main results of the paper suggest the solution of the following research objectives: 1) to analyse the first period of Russian Indology of middle XVIII - early XIX centuries as practically-linguistic and trace its origin and early stages of development; 2) to evaluate the second period of Russian Indology of the second half of XIX - the first decade of $\mathrm{XX}$ century as cultural and philological and designate its university character with the formation of the national scientific school of Indology; 3) to analyse of the third period of Russian Indology of 20-80-ies of XX century as generalizing sociological and to show its academic character with the preservation of scientific and pedagogical succession of indologists; 4) to assess the fourth period of Russian Indology of 90s of XX - early XXI century as conceptual - factual and to determine the nearest prospects. Article materials may be useful in determining the actual directions of traditional and new issues of Russian Indology. Statement of the designated problems is the formation of a new understanding of the history of Russian-Indian relations corresponding to modern scientific and social realities and expanding the historiographical knowledge about the past and prospects of these relations.
\end{abstract}

Keywords: Russian Indology, periodization, science and education organization, problematics and specialization

\section{Introduction}

Domestic indology is organically connected with the social, scientific and educational origins of Oriental Studies, perspective schools and trends, leading trends and patterns of oriental science and education. At current stage a systematic and comprehensive analysis of the Oriental Studies phenomenon, broader and deeper understanding of the scientific process, depending on the specific socio-historical conditions, education and other factors were conducted.

Modern Russian Orientalists and Indologists, representatives of the Kazan School - Professor Ramil Valeev Mirgasimovich (Valeev, 1998), Associate Professor Guzel Ferdinandovna Mrathuzina (Mrathuzina, 2001) and other declared themselves as respected scientists. Today, the contribution of local indologists in the world science is undeniable. The modern state is characterized by the activation of the research subject and object. Notably, that today there are publications of studies including the indicated authors of various aspects of this theme in English (Mrathuzina \& Maslova, 2015; Mrathuzina \& Tuhvatullin, 2015; Mrathuzina, Fayzullina \& Saglam, 2015).

However, the key point is a consideration of the historical and scientific landmarks of Russian Indology. Scientific and objective study of Indology history is a task of modern domestic and world Orientalism. Today it 
is necessary to make some corrections in chronological boundaries and essential components of each of the periods of the subject indicated by us.

Of course, domestic oriental studies are supplemented with original research that allow us to determine the level of study condition of Indology history in Russia. Currently partially reconstructed socio-cultural and ideological context of Indology influenced the growth of knowledge about India and the fate of Russian Indology. Application in modern studies of new methods of scientific analysis appears to be interesting.

Nevertheless, to our opinion, we have to give generalizing evaluations and imagine the development of Russian Indology in the context of domestic and world Oriental Studies. The system of modern Indological studies are needed to preserve the achievements and heritage of previous generations of scholars and practitioners, to identify the extent of their personalities that will determine the succession of the research. Russian authors need to broaden and deepen the research subject matter. Domestic research should bring an objective study of the theme "Russia-India" to a more qualitative level. The authors should reasonably cover the known and unknown pages of the history of relations between Russia and India.

In our opinion, the problem of studying of the Russian-Indian relations in Indian historiography is perspective. Urgent task is the problem of establishing relations with the leading centres of science and education of Great Britain and India.

Importantly, to identify the significance of the research tradition in the history of Domestic Indology it is necessary to use the latest research of domestic authors that will establish the current level of problem development. In addition, in such works very often the experience of the previous historiography theme is taken into account.

It is necessary to take into consideration that history study of Russian Indology should disclose the evolution of ideas and theories. Among the urgent tasks is clarification of the genesis of knowledge about India in Russia and reporting of formation and development determinants of Russian-Indian relations. Theoretical foundations and methodology of these studies, the specific experience of studying of Russian-Indian relations history will be a productive base of modern historiographical researches.

Today, the historical and cultural image of India in Russia is based on the strategic partner mutual relations (Kovaleva, et al, 2015; Gafiyatullina, et al, 2015). Tatarstan and India have identified areas of cooperation, including scientific and cultural. Currently, there is a need to continue the tradition of Kazan scientific school of Indology in the historical and cultural sense.

\section{Methodological Framework}

Indology in Russia formed and developed as an independent branch of knowledge, and of course had its own research functions.

By the 50th of XX century a special branch of Indology - its history - was formed. In 1946, the Institute of Oriental Studies of Academy of Sciences of USSR organized Indological session. In June 1947, a joint session of several branches of the Academy of Sciences of USSR devoted to the study of India was held. Specific studies on the Soviet Indology problems appeared. Problems of Russian-Indian relations are considered at the I All-Union Conference of Orientalists in 1957, and in 1963 - on the XXVI International Congress of Orientalists. Problems of historical and cultural relations with India in the studies of Soviet authors appear in foreign periodicals. The concept of "Indology" is given in the historical encyclopaedia. A new direction of Soviet Indological literature review is formed.

The problem of the historiography of the East countries has been stated to the mid-60s of XX century. By the end of the 70s, this problem has been formulated in the context of international relations. Indology is considered an integral part of Oriental Studies. Issues of complex analysis of Indology were considered in the context of domestic Oriental Studies. The self-analysis problem is partially solved by the mid 80s of XX century.

By the 80s of XX century, the domestic disciplinary status of historiographical research is formed in domestic indology. This scientific process was largely associated with domestic historiographical research, mainly affecting certain aspects of Russian-Indian relations, for example, cultural.

By the 90s of XX century and the beginning of this century, the historical and scientific analysis allows us to represent the nature, function, role and place of historiographical research in the history of Russian Indology, and specifically Russian-Indian relations. Historical and scientific studies allow to understand the phenomenon of Russian Indology and trace the paths and patterns of its development, to reveal not only a diverse empirical material, but also to summarize the theoretical foundations of historiography. Modern scientific and historical 
researches could contribute to the logical and analytical interpretation of the history of domestic Indology. At the present stage, one of the main tasks of Indology is to analyse the origin and development of ideas, problems and methods of the humanities.

Today it is important to be able to justify the use of the methodology and methods of research. The methodology promotes the learning of previous development practice of scientific thought, diversity of scientific perspectives, methods and techniques of research.

One of the important tasks of the methodology is identifying the nature, purpose and specific methods of historiographical work. Until recently, logic, conditions and factors of progressive or regressive development of Russian Indology, ideas development and actual problems of the humanities were remained uninvolved. In recent decades, scientific and historical and historiographical studies have demonstrated the broadening and deepening of the subject matter, and historians' professionalization. Traditional approaches diffusion is traced. An extensive literature on the history of Indology allows to recreate the picture of the development of the science of India history and culture.

Systematic approach, developed in scientific research makes it possible a comprehensive consideration of the system of historiography and source studies. It extends the system presentation of factors, conditions and nature of the formation and development, differentiation and integration of scientific knowledge about India. The systematic approach method allows to cover all the main components of practical and scientific Indology in the interaction and mutual influence. Russian Indology represents an integral complex with internal and external patterns of formation and development as a systemic factor of the whole domestic orientalism. System analysis allows to avoid the unilaterality and schematism in problems interpretation.

Comparative-historical method of comparison, collation, parallels is of fundamental importance. This method makes it possible to illuminate the formation and development of Indology in Russia in close connection with the social and political situation of a particular era. The comparison of practical and academic Indology is of particular importance. Comparative-historical method allows to compare historiographical facts and sources that were not previously known to already introduced in the scientific revolution.

The method of periodization of the history of Russian Indology allows to single out periods and stages, which are qualitatively different in its formation and development. At the heart of periodization are certain factors and criteria - objective and subjective elements of scientific thought development about the history and culture of the Russia and India peoples' relationship, qualitative changes in the system of education and science, organizational forms of Indology in Russia, research methods and the nature of teaching and research activities of Russian Indologists. Periodization method allows to create a dynamic image of a progressive or regressive Indology in Russia. Historians suggest criteria for periodization connected with the development of science itself, changing of approaches and guidelines. There can be scientists, ahead their era, but more often, researchers, following the standards of the era. There can be "archaic" scientists, which scientific researches may become irrelevant and uncharacteristic at some stage.

Retrospective method is a return gaze from the present to the past. Using the method of retrospection, we can judge science as per the era and the state of the science at the previous stages. However, it should be appreciated that the historiographer does not have the right to look at previous stages the ideas, which could not yet be historical. About the significance of certain works for the development of scientific thought, we can judge primarily on the basis of the time of their creation. Every scientific work belongs to its epoch and bears its strengths and weaknesses.

The historicism method allows to consider events and phenomena in a time sequence and regular succession. Each of the historical and scientific stages is analysed as a relatively independent and complete cycle with its peculiar certain organizational, educational, scientific elements. Indology as an educational and scientific system studied by us in chronological order, historical and conceptual unity. Real historiographical facts and sources connected with the Russian indology are considered from the point of view of their succession. Events of science and practice are closely linked with the historical conditions - economic, social and spiritual processes in the Russian Empire, the Soviet Union and the Russian Federation. During the XIX-XX centuries, indological tradition played an important role in the history of Russian peoples' culture.

Synchronous method includes the study of various events and phenomena simultaneously. Application of this method makes it possible to identify common and specific features. The combination of synchronous method with chronological allowed to consider the phenomenon in interrelation and successive change of practice and science of India. 
The actualization method allows to build scientific predictions of Indology development in Russia by identifying its major trends.

Prospects accepting allows to determine the perspective educational and research trends of domestic Indology.

Such theoretical and methodological approaches implemented by domestic orientalists, when introduced, for instance, methods of periodization associated with the change of attitudes and orientations, coverage of issues and specialization, tendency to generalize, links with the practice, the ratio of the past and present, links with other areas of knowledge and the world science in general, organization and communication with study areas. A wide range of problems of modern Oriental Studies is analysed and refined: evaluation of pre-revolutionary Orientalism, development and change of scientific concepts, book publishing. A lively and fruitful discussion is developed on all these issues.

Thus, the theoretical and methodological research methods make it possible to study dialectically and deepen the scientific basis of the history of Russian Indology. In the history of relations between Russia and India can be traced general social and general scientific values, influence of the ideology and practice of the state, socio-cultural factors, the system of universal and intrascientific ethical standards.

\section{Results}

Domestic indology needs solving of chronological and essential systematization problems. Scientific and historiographical boundaries of this article allow to dwell just briefly on the analysis of the main periods.

First period. The science of India becomes the object of study of the first Russian historians and orientalists. The origins of historical and scientific knowledge of India in Russia formed to the middle of the XIX century. These materials are characterized by rational formation and justification of facts. The study of the history of Russian Indology connected with long tradition going back to works of domestic indologists of the first half of the XIX century. The first studies devoted to Indology in Russia were already self-awareness of science.

The principal features of the pre-revolutionary Russian Indology of the first half of the XIX century. - Formation of the basic concepts and trends are presented by the names of Russian Indologists: Robert Christianovich Lentz standing at the origins of the study of Indian philology; Fedor Pavlovich Adelung, as a historian and linguist; Otton Karlovich Betlingk, whose scientific contribution was the compilation of Sanskrit dictionaries and various textbook - practical grammars and anthologies. The successes of the arising national school of Indology connected primarily with Kazan University. The libraries of the University had all the latest European research in Indology. Here were collected rare oriental books and manuscripts on various branches of Oriental Philology and Ethnography. A great merit belongs to the University Rector Nikolai Ivanovich Lobachevsky. His desire to establish scientific relations with the countries of the East was obvious. Scientific information was directed in the university, Indian manuscripts and books were acquired for the university, the Asian Museum and the Public Library. Kazan University was presented by the names of Fedor Fedorovich Bolenzena and Pavel Yakovlevich Petrov (Khayrutdinov, 2014).

Historiography and source study materials on the history of Russian-Indian relations appear simultaneously with the emergence of the science of India. Communication of the forming Indology with the problem of Russian-Indian relations study becomes not accidental, and acquires a systematic and comprehensive character.

Second period. At the turn of the XIX and XX centuries developed historiography and source study traditions of Russian Indology. Domestic historiography has fulfilled a part of facing her problems. Studies covering the pages of the history of Russian Indology have been published. Historiographical analysis shows that many of the works and articles were devoted to subjects related to Russian-Indian relations. However, the history of these relations in the studies was covered in fragments.

In the second half of the XIX century the process of Indology scientific school birth is going. The official status of Oriental studies is concentrated in the Lazarev Institute in Moscow and Faculty of Oriental Studies of St. Petersburg University, where the careful preparation of Indological staff is executed, Ivan Pavlovich Minaev and his students - Sergey Fedorovich Oldenburg and Fedor Ippolitovich Shcherbatskoy are became recognized.

At the beginning of the XX century, a general for the humanities the paradigm shift process played the role. Researchers acquire new scientific methods and evaluate the history of Russian Orientalism as an integral part of scientific knowledge and culture of the society. They formulated ideas about the subject, objectives and role of the history of relations between Russia and India. The activity of a number of prominent indologists, their scientific and educational heritage played a particular role and made an entire era. Their works are a generalization of key results of Indology in pre-revolutionary Russia. 
Historical events in Russia in the first decades of the XX century became a turning point for the Russian Oriental studies, including Indology. The problem of generating of revolutionary schemes and Marxist approaches to the study of the history and culture of the East became urgent. If before 1917, the Russian Orientalists were an impressive squad of specialists in the international community, after 1917 there was a decline of classical Oriental studies.

Third period. In the 20-30-ies of the XX century appear a new generation of professionals. The Soviet Orientalism developed, overcoming the contradictions and difficulties. Leningrad school was based on a solid scientific classic basis, Moscow - on the teachings of Marxism-Leninism, considered at that time the most advanced method of historical analysis.

In the postwar years, problems of the scientific school of Indology are noticeable because of the physical loss of many experts. The solution of this problem lies with the scientists whose childhood or adolescence was in the years of the Great Patriotic War and in the postwar period. Political and theoretical problem was the transition of society in all its diversity, above all, political and ideological. This generation of scientists had to investigate and assess the changed political situation in the Afro-Asian region. Doing this was difficult not only because of the novelty, uniqueness and complexity of the processes in the East, but also because of the dogmatic school of a past age. The weakness of the works of 1940-50-ies is adherence to the political and ideological conjuncture of time.

The "ideological thaw" time has stimulated theoretical research on the history of India. 1960s is the stage of fundamental understanding of the problems of the East connected with the process of decolonization of the East and the phenomenon of the developing world. Turning events in the history of India (achievement of independence in 1947, the proclamation of the republic in 1950) are reflected in the national historical science. Objective circumstances have left their mark on the research of scientists of this decade. Firstly, intelligence of the awakened East created their own scientific schools. National historic centres appeared. Work of the national archives and libraries were changing. Orientalism acquired the original database and the new starting point. Secondly, the domestic orientalists had an opportunity to make field trips to the countries studied.

In Soviet archeology dominated thematic publications, which were subject to all the features of the era, time and situation. However, they often were not intentional, and they were due to the modern level of social and political evolution or development of sources. It is necessary to take into account that the selection of documents, completion of their submission, comments - all of which can be tendentious or subjective. For example, dialectics study of the history of Russian-Indian relations in historiographical terms determined not only by the patterns of the object of study, but also the needs of the time. Historical literature inevitably reflected the influence of the era and historical periods. The subjective views of the authors of research are also traced in it. In historical studies can be found all - from unintentional errors to deliberate fraud. This should be considered when using a variety of literature. Although any kind of work should be assessed in the first place, from the point of view what new it contributed, and not just from today's perspective.

However, exactly in Soviet times, Oriental centres of the USSR are finally formed, a summary researches on India are issued, representatives of the Soviet school of Indology are formed - Leonid Borisovich Alaev, Gregoriy Mikhaylovich Bongard-Levin, Alexey Aleksandrovich Vigasin and others.

Publications of pre-revolutionary and Soviet researchers of history of Russian-Indian relations were based on the original materials. Unfortunately, their contribution was not fully appreciated. Only at the end of XX century based on various archival and historiographical material, manuscripts and rare books the summary studies were published. Systematic studies of pre-revolutionary and Soviet periods meant the revival of traditions of interrupted science of the second half of the XVIII- early XX centuries.

Fourth period. By the 90s of XX century, ideological and administrative-political character of the influence of Marxist methodology of history in the Soviet Orientalism weakens. In the last decade of XX - the beginning of XXI century begins the outdated stereotypes breaking. Researchers emphasise civilizational and religious and cultural factors of world history study. The East countries study deals with the problems of revaluation of historical process originality in the East, the mechanisms of transformation and western influences.

Evaluation of modern India becomes associated with certain features of its civilization, ideological and cultural identity, as well as the influence of Indian culture on the world.

In modern Russian historiography, there were many comparative cultural studies of historical and cultural reflection of heritage of India in the culture of Russia. Modern theoretical arguments turned out that the cross-cultural ties between Russia and India were significantly singled out in the context of East - cultural 
orientation of the West. These ties are characterized by its versatility, creative synthesis and harmony. Despite the contrasts in lifestyle, mentality and cultural identity, the Russian-Indian relations have long traditions. They were not darkened by military conflicts, political confrontation, commercial rivalries and ideological incompatibility. Not taking until a certain time a form of inter-state relations and not getting a solid diplomatic status, they were nonetheless based on a strong cultural value basis.

Exactly in the cultural paradigm, the relations between Russia and India have gained an adequate place of their role and relationship system. Modern authors draw their image of India, found different points of counting and the original reference framework, avoiding rectilinear and dogmatic opposition of East and West. They comprehend India in new ways. We had to deal with the author's position, a certain style and genre. Domestic indology distinguished not only by the accumulation of vast factual historical material, but also by achievements in the field of language, literature and culture of India.

In general, new prospects for the Russian Indology are opened. Historiographical and scientific innovations begin to testify to the present level of research subject "Russia-India." In recent decades, continue their studies the leading indologists of the countries, especially workers of the Centre for Indian Studies of Institute of Oriental Studies RAS - Anatoly Akimovich Kutsenkov, Tatiana Nikolaevna Zagorodnikova, Tatiana Lvovna Shaumyan, Eugene Yurievna Vanina, who focus mainly on the image of India in Russia and Russia in India, giving them positive characteristics and saturation of new content.

\section{Discussions}

Works of our authors, one way or another affecting our subject, differ in scientific level and factual and other research material content, which allows to group them as follows.

First of all, it is works of a general character. Questions of modern Indology increasingly are studied in the framework of oriental research direction. An important trend in the field of domestic Oriental Studies is archive studies. Many original creative works based on a variety of sources with research generalizations, new approaches and ideas were published. (Valeev \& Martynov, 2009) In recent years, range of research sources has been expanded. Became available archival materials and many of them declassified "limited access". A lot of literature and sources, including documents, memoirs, and periodicals were transferred to the free access from special funds of the libraries. Began to receive more sources on the history of relations between Russia and India from abroad. Increased the informational capabilities of reading of sources, introduced in the scientific revolution, through deideologization of source study, refusal from non-schematic approaches and absolutization of reliability degree of individual groups of sources. It provides a framework for attraction of a wide range of sources, their analysis.

Critical reviews of works of indologists well known in the past are worth noticing by researchers. These works are related to various subjects and types: Biobibliographic material (Young Orientalists of the Commonwealth of Independent States, 2010; About colleague and friend: Moscow Orientalists, 1994); official material is official documentation, reports, notes (Archive of Orientalists, 1990; Notes of the Eastern Branch of the Russian Archaeological Society, 1994); material of personal origin is travel essays, letters, diaries, memoirs (Lebedev, 2009; Nikitin, 2003).

Textbooks enable to get an idea of the subject place, allow to focus on issues of methodology, current approaches to the history of Oriental studies (History of Russian Oriental Studie, 1997; On the history of Russian Orientalism, 2000). Today textbooks on modern Indian history are published (The history of the twentieth century India, 2010). Modern historiography has studied a wide range of subjects, problems, private issues of India (India: in short everything, 2009; India: the country and its regions, 2000).

Materials of discussions and scientific conferences in which the theme and its components have been the subject of a special discussion are of great interest. (Actual problems of Indology in Russia and abroad, 2013; India: perspectives of modern development. Domestic, regional and global aspects, 2012)

Studies of the political relations between Russia and India have been reflected in the essays on the theme of adaptation of Russia and India to the changed conditions in the world. The concept of the majority of the authors based on the idea that the collapse of the centralized state, connected primarily with the Russian Empire and then with the Soviet Union, does not mean the end of historical relations. Interaction between Russia and eastern regions is a constant factor in its history, "Eurasian" origin in civilizational aspect of Russia and an essential component of its socio-cultural and geopolitical organization. Address to the latest basic research is particularly appropriate in connection with recent events. (Shaumyan, 2009; Shaumyan, 2000)

In recent years, national historiography develops such direction as Comparative studies, which is represented by 
the cultural works that are relevant for understanding of the internal senses of culture and learning of wide horizons of cultural enrichment. (Gachev, 1993)

The problem of "Russia-India" is considered today in the context of the "West-Russia-East", of the Eurasian origin in Russia, mentality of intercultural communication. Interesting is the problem of the so-called "Feedback", i.e. the study of the image of Russia in India. Appeared the first in domestic research science on the characteristics of the formation of Russia's image in the mass consciousness of the peoples of India, giving to it positive characteristics and saturation of new content. (Zagorodnikova, 2008; Shaumyan, 2011)

Our study focuses on the analysis of the phenomenon of Russian Indology, calling for the preservation of succession in studies, evaluation of the accumulated scientific knowledge of Russian Indology and creative heritage of Russian Indology. Approach to the study of India is highlighted by the academic and creative interests of the author of this article to the problems of the "Russia-India", which will conclude about the traditions and innovations of Russian Indology. We believe that to the preceding stages of the history of Russian Indology we obliged the accumulated scientific experience, because domestic indologists demonstrated the emergence of a unique science of the spiritual world of the peoples of India, opened the ideological and aesthetic and scientific value of historical and cultural heritage of the peoples of Hindustan. Considered aspects of the designated theme were not considered in previous studies.

\section{Conclusion}

Analysis of historical and historiographical sources on this topic allows to get the necessary information for the successive concrete historical, historiographical and source-study subject study.

When reporting the material the provision of research sources, introduced in the scientific revolution were taken into account. The process of development of sources clarifies many facts and events in the history of Oriental and Indological science. The complex of source material has made a significant contribution to the interpretation of the problem of "Russia-India." It was the original basis for the development of Russian Indology as an academic discipline. Using of the enormous amount of factual material, reflected in Archeology of the past and present, is estimated by the real facts of expansion and deepening of scientific knowledge about the history of Russian-Indian relations.

Modern studies are correspond with trends of the development of sources and requirements, determined by practical experience of previous generations of researchers. The theme of "Russia-India" has become a priority in the work of local historians. A domestic historiography and source study of Russian Indology demonstrated a high level of scientific research.

If we judge about the source study level of our theme research as a whole, we can say about the authenticity and representativeness of source study material.

Critical analysis of the historiographical sources suggests making a conclusion about the level of study subject in whole and in its individual aspects. It is necessary to avoid a single-valued evaluation of national historiography stages of "Russia-India" problems. We pay a special attention to the work of scientists who have made a significant contribution to the research topic. Research practice of modern Russian Indology seems to be a natural process of the genesis of science in the preceding stages.

Russian orientalist made a thorough analysis of the leading issues of national science of India. System of scientific laboratory formation of indologists, their scientific achievements and creative biography is presented in general works on the history of Domestic Oriental Studies. Works in the field of domestic Indology fall in the outline of the analysis of Oriental studies.

In general, domestic oriental studies and Indology are developed rapidly and dramatically. In recent years, the study of problems of the Russian-Indian cultural interferences became more intense, systemic and the most popular.

\section{Acknowledgments}

The work is performed according to the Russian Government Program of Competitive Growth of Kazan Federal University

\section{References}

Actual problems of Indology in Russia and abroad: Proceedings of the 2013 All-Russia Roundtable. Kazan: Institute of International Relations, History and Oriental Studies of the Kazan Federal University. 
Archive of Orientalists. (1990). In Written monuments and problems of the history and culture of the peoples of the East (Part 3, pp. 5-128). Moscow.

Gachev, G. D. (1993). Images of India: the experience of existential cultural studies. Moscow: Science.

Gafiyatullina, A. Z., Nikonova, T. V., Vagin, S. G., Kharisova, R. R., Pavlova, E. I., Khayrutdinov, R. R., \& Ishmuradova, I. I. (2015). Organization of Controlling the Intellectual Potential of Company Personnel. Review of European Studies, 7(4), 13-19. http://dx.doi.org/10.5539/res.v7n4p13

India: in short everything. (2009). Moscow: Natalis.

India: perspectives of modern development. Domestic, regional and global aspects: Proceedings of the 2012 Scientific and Practical Conference. Moscow: Institute of Oriental Studies of the Russian Academy of Sciences.

India: the country and its regions. (2000). Moscow: Centre for Indian Studies.

Institute of Oriental Studies of the Russian Academy of Sciences. (1994). About colleague and friend: Moscow Orientalists. Moscow: Institute of Oriental Studies.

Institute of Oriental Studies of the Russian Academy of Sciences. (1997). History of Russian Oriental Studies. Moscow: Eastern Literature.

Institute of Oriental Studies of the Russian Academy of Sciences. (2010). The history of the twentieth century India. Moscow: Institute of Oriental Studies of the Russian Academy of Sciences.

Institute of Oriental Studies of the Russian Academy of Sciences. (2010). Young Orientalists of the Commonwealth of Independent States. Moscow: Institute of Oriental Studies.

Khayrutdinov, R. R. (2014). Museum Conference of 1926 in Kazan. World Applied Sciences Journal, 31(2), 193-195.

Kovaleva, N. I., Valeyeva, N. S., Avilova, N. L., Kharisova, G. M., Khayrutdinov, R. R., Khairullina, E. R., \& Shaikhlislamov, A. K. (2015). Recommended Practices for Improving the Competitiveness of the Russian Education Services Market under the Conditions of the International. Review of European Studies, 7(4), 1-5. http://dx.doi.org/10.5539/res.v7n4p1

Lebedev, G. (2009). Impartial contemplation systems in Eastern India bragmenov, their sacred rites and folk customs. Yaroslavl: Development Academy.

Moscow State Institute of International Relations. (2000). On the history of Russian Orientalism. Moscow: MGIMO.

Mrathuzina, G. F. (2001). Russian-Indian relations in the national historiography (Unpublished master's thesis). Kazan: State University.

Mrathuzina, G. F., \& Maslova, E. S. (2015). Russian historiography and source studies of the problem of «Russian threat» to India within the context of Anglo-Russian relations. Social Sciences, 10(2), 117-120.

Mrathuzina, G. F., \& Tuhvatullin, A. H. (2015). Russian Historiography of Sources of Historical Links of Volga Region and India. Social Sciences, 10(2), 121-125.

Mrathuzina, G. F., Fayzullina, A. R., \& Saglam, F. A. (2015). Substantive, Methodological and Organizational Discourse in Oriental History Learning at School and University. Review of European Studies, 7(1), 57-62.

Nikitin, A. (2003). Journey Beyond Three Seas Athanasius Nikitin. Tver: Printshops Tver region.

Notes of the Eastern Branch of the Russian Archaeological Society. (1994). In History, historiography, library (pp. 49-67). Moscow.

Shaumyan, T. L. (2000). Russia-India: prospects for cooperation in the XXI century. Moscow: Institute of Oriental Studies of the Russian Academy of Sciences.

Shaumyan, T. L. (2009). India - Russia: Partnership Strategy in the XXI century. Moscow: Institute for Economic Strategies.

Shaumyan, T. L. (2010). The main priorities of Indological studies. Moscow: Institute of Oriental Studies.

Shaumyan, T. L. (2011). Russia's image in the public mind of India: Past and Present. Moscow: Science.

Valeev, R. M. (1998). Kazan Orientalism: The Origins and Development (XIX - 20 years. XX century). Kazan: Publishing House of Kazan University. 
Valeev, R. M., \& Martynov, D. E. (2009). Russian university Orientalism in archival documents: centers, events and heritage. XIX - early. XX century. Kazan: Kazan State University.

Zagorodnikova, T. N. (2008). Formation of the image of Russia in India in the nineteenth - early twentieth century. Moscow: Eastern Literature.

\section{Copyrights}

Copyright for this article is retained by the author(s), with first publication rights granted to the journal.

This is an open-access article distributed under the terms and conditions of the Creative Commons Attribution license (http://creativecommons.org/licenses/by/3.0/). 